\title{
PENGARUH PEMBERIAN ASAM TRANEKSAMAT TERHADAP JUMLAH PERDARAHAN PASCASALIN PADA KELAHIRAN VAGINAL
}

\author{
Laili Chilmawati ${ }^{1}$, Heru Pradjatmo ${ }^{2}$, H.R. Siswosudarmo ${ }^{3}$
}

\begin{abstract}
Background: Maternal mortality is the great problem in developing countries and postpartum hemorrhage is the main cause. Obstetrics intervention and uterotonics agents have been used to control postpartum hemorrhage, but the use of hemostatic agent is still in the study.

Objective: To compare the effect of tranexamic acid on postpartum hemorrhage and its potential side effects compared with placebo in vaginal delivery

Methods: A Double blindrandomized controlled Trial (RCT). We conducted a total of 198 subjects who met the inclusion criteria were recruited. The treatment group was those who got one gram tranexamic injection and the the control group those who got placebo. Independent sample t-test, chi-square and linear regression were used for statistical in treatment group analysis.

Results and Discussion: A total of 198 subjects met the inclusion criteria, consisting of 99 subjects and 99 in the control group. No significant difference was found on the amount of postpartum hemorrhage $(102.13 \pm 67.34 \mathrm{ml}$ $v s .110 .58 \pm 73.57 \mathrm{ml} ; p=0.40)$, nor on the difference of hemoglobin level $(0.99 \pm 1.13 \mathrm{~g} / \mathrm{dLvs} .1 .05 \pm 0.93 \mathrm{~g} / \mathrm{dL} p=0.66)$,

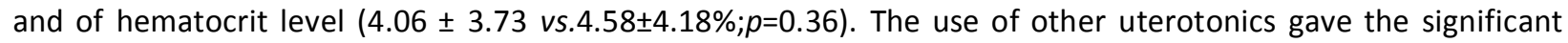
difference at the decrease of hemoglobin level $(p=0,02)$. Side effect of nausea and vomiting at tranexamic acid group didn't differ from placebo $(p=1,00)$.

Conclusion: There was no difference between the use of tranexamic acid and placebo in terms of number of bleeding the decrease of haemoglobin and hematocrit.
\end{abstract}

Keywords: tranexamic acid; postpartum hemorrhage; hemoglobin and hematocryte level, vaginal delivery.

\begin{abstract}
ABSTRAK
Latar belakang: Kematian ibu merupakan masalah yang besar di negara sedang berkembang. Perdarahan pascasalin merupakan penyebab paling utama kematian ibu. Intervensi obstetrik dan obat-obat uterotonika telah digunakan secara optimal untuk mengatasi perdarahan pascasalin, tetapi obat hemostatik masih dalam kajian.

Tujuan: Mengetahui pengaruh asam traneksamat terhadap jumlah perdarahan pascasalin pada persalinan vaginal dan efek samping yang mungkin terjadi.

Metode Penelitian: Metode penelitian ini adalah Randomized Controlled Trial (RCT). Subyek penelitian adalah pasien dengan persalinan vaginal yang memenuhi kriteria inklusi dan eksklusi. Kelompok penelitian adalah mereka yang mendapat injeksi asam traneksamat 1 gram intravena sedang kelompok control adalah mereka yang mendapat plasebo. Independent $t$-test, chi-square dan regresi linier digunakan untuk analisis statistika.

Hasil dan Pembahasan: Sebanyak 198 subyek memenuhi memenuhi kriteria kelayakan, terdiri atas 99 subyek masuk ke dalam kelompok perlakuan dan 99 subyek yang masuk dalam kelompok kontrol. Tidak didapatkan perbedaan secara bermakna pada jumlah perdarahan kala IV $(102,13 \pm 67,34 \mathrm{ml}$ vs 110,58 $\pm 73,57 \mathrm{ml}, p=0,40)$, penurunan kadar hemoglobin $(0,99 \pm 1,13 \mathrm{~g} / \mathrm{dLvs} .1,05 \pm 0,93 \mathrm{~g} / \mathrm{dL}, p=0,66)$ dan penurunan kadar hematokrit $(4,06 \pm 3,73$ vs. $4,58 \pm 4,18 \%, p=0,36)$. Penggunaan uterotonika lain memberikan perbedaan secara signifikan terhadap penurunan kadar hemoglobin $(p=0,02)$. Kadar hemoglobin awal dan kadar hematokrit awal memberikan
\end{abstract}

PPDS 1 Obstetri dan Ginekologi, Bagian Obstetri dan Ginekologi, Fakultas Kedokteran Universitas Gadjah Mada

2,3 Bagian Obstetri dan Ginekologi, Fakultas Kedokteran, Universitas Gadjah Mada 
perbedaan secara signifikan terhadap penurunan kadar hematokrit ( $p=0,006$ dan 0,01$)$. Kejadian efek samping mual dan muntah pada pemberian asam traneksamat tidak berbeda dibandingkan dengan plasebo $(p=1,00)$. Kesimpulan: Jumlah perdarahan kala IV, penurunan kadar hemoglobin dan penurunan kadar hematokrit tidak berbeda antara kelompok yang mendapat asam traneksamat dibanding yang mendapat placebo.

Kata kunci: asam traneksamat, perdarahan pascasalin, kadar hemoglobin, hematokrit.

\section{PENDAHULUAN}

Kematian ibu merupakan masalah yang besar di negara berkembang. Menurut WHO (2012), kematian ibu di negara berkembang sebesar 240 per 100.000 kelahiran dan di negara maju 16 per 100.000 kelahiran. Penurunan angka kematian ibu sebanyak 75\% antara tahun 1990-2015 merupakan salah satu tujuan Millenium Development Goals V (MDG'sV). ${ }^{1}$ Menurut Survei Demografi dan Kesehatan Indonesia tahun 2012, angka kematian ibu (AKI) di Indonesia

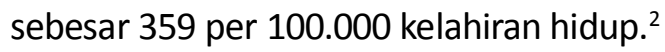

Perdarahan pascasalin merupakan penyebab paling utama kematian ibu di seluruh dunia, termasuk di Indonesia. Penyebab perdarahan pascasalin berupa tonus (atonia uteri setelah persalinan), tissue (retensi produk konsepsi atau jendalan darah), trauma (jalan lahir) atau thrombin (abnormalitas koagulasi). ${ }^{3}$

Intervensi obstetrik dan obat-obat uterotonika telah digunakan secara optimal untuk mengatasi perdarahan pascasalin. Sebaliknya, abnormalitas hemostatik pada perdarahan pascasalin yang seharusnya dipertimbangkan sebagai konsekuensi perdarahan yang tidak terkontrol belum diterima sebagai terapi spesifik. Obat-obat hemostatik belum secara rutin diberikan sebagai obat lini pertama pada perdarahan pascasalin. ${ }^{4}$

Asam traneksamat telah digunakan secara luas untuk menurunkan kehilangan darah pada pembedahan dan kondisi kesehatan yang berhubungan dengan peningkatan jumlah perdarahan. ${ }^{4}$ Beberapa faktor risiko tinggi yang berhubungan dengan perdarahan pascasalin seperti plasenta previa dan laserasi jalan lahir, memberikan respon terhadap asam traneksamat.
Tujuan penelitian ini adalah untuk membandingkan pemberian asam traneksamat dengan placebo dalam hal banyaknya perdarahan kala IV pada persalinan vaginal.

\section{BAHAN DAN CARA KERJA}

Rancangan penelitian adalah double blinding Randomized Controlled Trial (RCT).Kriteria inklusi adalah pasien pascasalin secara vaginal, spontan, hamil aterm (37-42 minggu), janin tunggal, hidup, lama persalinan dalam batas normal (kala I antara 4 sampai 24 jam, kala II kurang dari 2 jam). Pasien dengan kelainan kehamilan dan persalinan, perdarahan karena atonia uteri tidak termasuk dalam penelitian ini.

Sampel penelitian diambil secara berurutan (consecutive sampling) sampai seluruh jumlah sampel terpenuhi yaitu sebanyak 198 buah. Sampel penelitian diambil dari populasi penelitian yang ada di Puskesmas Tegalrejo, Puskesmas Mergangsan dan RSUD Panembahan Senopati Bantul. Subyek penelitian yang memenuhi kriteria kelayakan dimasukkan dalam sampel penelitian sesuai dengan nomor urut randomisasi.

Randomisasi pada penelitian ini dilakukan oleh pihak ketiga, yaitu Bagian Instalasi Farmasi RSUP Dr. Sardjito Yogyakarta. Tabel bilangan random berdasarkan bilangan komputer. Obat dilabel dengan A dan B dan baru dibuka setelah analisis selesai. Sebelum penelitian dimulai pasien sudah menandatangani informed consent.

Manajemen aktif kala III dilakukan pada setiap pasien. Kelompok perlakuan mendapat obat $A$ intravena segera setelah bayi lahir, dan kelompok kontrol mendapat obat $\mathrm{B}$ dengan prosedur yang 
sama. Setelah plasenta lahir dilakukan penggantian underpad kosong. Setelah 2 jam pascasalin, dilakukan penimbangan underpad dan penghitungan jumlah kassa. Jumlah perdarahan diukur setelah dilakukan penimbangan underpad dan penghitungan jumlah kassa. Kadar hemoglobin dan hematokrit diukur pada saat pasien datang dan setelah 24 jam pascasalin.

Luaran yang dinilai adalah jumlah perdarahan kala IV, penurunan kadar hemoglobin, dan penurunan kadar hematokrit. Jumlah perdarahan diukur berdasarkan selisih berat underpad setelah persalinan dikurangi rerata berat underpad, dan dikurangi rerata berat kassa x jumlah kassa yang digunakan. Berat dalam gram dikonversi menjadi ml. Satu gram setara dengan $1 \mathrm{ml}$. Kadar hemoglobin dan hematokrit dilakukan di Laboratorium Klinik dengan menggunakan mesin analisis hematologi Sysmex yang telah dikalibrasi.

Hasil penelitian ini dianalisis dengan analisis bivariat menggunakan independent T-Test dan Chisquare. Analisis multivariat menggunakan regresi linier.

\section{HASIL DAN PEMBAHASAN}

Sebanyak 198 subyek penelitian memenuhi kriteria analisis. Kedua kelompok bersifat komparabel seperti terlihat pada tabel berikut.

TABEL 1. Komparabilitas antar kelompok penelitian

\begin{tabular}{|c|c|c|c|c|c|}
\hline \multirow{2}{*}{ Variabel } & \multicolumn{2}{|c|}{$\begin{array}{c}\text { Asam } \\
\text { Traneksamat }\end{array}$} & \multicolumn{2}{|c|}{ Plasebo } & \multirow[t]{2}{*}{$p$} \\
\hline & $\mathrm{N}$ & $\%$ & $\mathrm{~N}$ & $\%$ & \\
\hline \multicolumn{6}{|l|}{ Umur (tahun) } \\
\hline$\geq 35$ & 12 & 12,1 & 18 & 18,2 & 0,26 \\
\hline$<35$ & 87 & 87,9 & 81 & 81,8 & \\
\hline \multicolumn{6}{|l|}{ Paritas } \\
\hline$\geq 3$ & 13 & 13,1 & 19 & 19,2 & 0,27 \\
\hline$<3$ & 86 & 86,9 & 80 & 80,8 & \\
\hline \multicolumn{6}{|l|}{ IMT } \\
\hline Obese & 15 & 15.2 & 19 & 19,2 & 0,45 \\
\hline Non Obese & 84 & 84.8 & 80 & 80,8 & \\
\hline \multicolumn{6}{|l|}{ Berat Janin (gram) } \\
\hline$\geq 3500$ & 15 & 15,2 & 14 & 14,1 & 0,84 \\
\hline$<3500$ & 84 & 84,8 & 85 & 85,9 & \\
\hline \multicolumn{6}{|c|}{ Penggunaan uterotonika lain } \\
\hline Tidak & 36 & 36,4 & 38 & 38,4 & 0,77 \\
\hline Ya & 63 & 63,6 & 61 & 61,6 & \\
\hline \multicolumn{6}{|l|}{ Robekan jalan lahir } \\
\hline Ya & 84 & 84,8 & 79 & 79,8 & 0,35 \\
\hline Tidak & 15 & 15,2 & 20 & 20,2 & \\
\hline \multicolumn{6}{|c|}{ Kadar hemoglobin awal (g/dl) } \\
\hline$<11$ & 7 & 7,1 & 6 & 6,1 & 0,77 \\
\hline$\geq 11$ & 92 & 92,9 & 93 & 93,9 & \\
\hline \multicolumn{6}{|c|}{ Kadar hematokrit awal (\%) } \\
\hline$<33$ & 3 & 3 & 2 & 2 & 0,65 \\
\hline$\geq 33$ & 96 & 97 & 97 & 98 & \\
\hline
\end{tabular}


Tidak terdapat perbedaan bermakna antara pengaruh pemberian asam traneksamat dan placebo terhadap perdarahan kala IV maupun penurunan kadar hemoglobin maupun hematokrit seperti terlihat pada tabel berikut.

TABEL 2. Pengaruh pemberian asam traneksamat terhadap jumlah perdarahan kala IV, penurunan kadar hemoglobin dan penurunan kadar hematocrit

\begin{tabular}{lcccccc}
\hline Variabel & N & Mean & SD & $\Delta$ Mean & $95 \% \mathrm{Cl}$ & $p$ \\
\hline Jumlah perdarahan kala IV & & & & & & \\
$\quad$ Asam traneksamat & 99 & 107,24 & 70,70 & $-8,86$ & $-29,62-11,89$ & 0,40 \\
$\quad$ Plasebo & 99 & 116,11 & 77,25 & & & \\
Penurunan kadar hemoglobin & & & & & & \\
$\quad$ Asam traneksamat & 99 & 0,99 & 1,13 & $-0,06$ & $-0,35-0,22$ & 0,66 \\
$\quad$ Plasebo & 99 & 1,05 & 0,93 & & & \\
Penurunan kadar hematokrit & & & & & & \\
$\quad$ Asam traneksamat & 99 & 4,06 & 3,73 & $-0,52$ & $-1,63-0,59$ & \\
$\quad$ Plasebo & 99 & 4,58 & 4,18 & & & \\
\hline
\end{tabular}

Penelitian ini selain menilai rerata jumlah perdarahan kala IV, juga menilai penurunan kadar hemoglobin dan hematokrit. Tidak terdapat perbedaan bermakna rerata jumlah perdarahan pada pemberian asam traneksamat dengan plasebo $(102,13 \pm 67,34 \mathrm{ml} v s .110,58 \pm 73,57 \mathrm{ml}, p=0,40)$. Selisih rerata jumlah perdarahan kala IV pada kedua kelompok adalah 8,45 ml. Hal ini berbeda dengan penelitian yang dilakukan Mayur dkk (2007), bahwa terdapat perbedaan secara bermakna antara pemberian asam traneksamat dan placebo tetapi penelitian ini adalah pada pasien seksio sesarea $(374,92 \pm 51,46 \mathrm{ml}$ vs. $472,79 \pm 43,54 \mathrm{ml}, p=0,003) .5$ Pada penelitian Gungorduk dkk (2011), juga didapatkan perbedaan secara bermakna antara pemberian asam traneksamat dan plasebo pada pasien seksio sesarea $(499,9 \pm 206,4 \mathrm{ml}$ vs. $600,7 \pm 215,7 \mathrm{ml}, p<0,001) .{ }^{6}$ Penelitian Gai dkk (2004), juga mendapatkan hasil perbedaan secara bermakna antara pemberian asam traneksamat dan plasebo pada pasien seksio sesarea $(359,29 \pm 152,02$ $\mathrm{ml} v$ s.439,36 $\pm 191,48 \mathrm{ml}, p=0,002) .7$

Penelitian ini mendapatkan hasil yang berbeda dengan penelitian sebelumnya. Perbedaan ini terletak pada subyek yang diteliti. Subyek penelitian sebelumnya dilakukan pada individu dengan perdarahan yang banyak, yaitu seksio sesarea dan persalinan vaginal dengan jumlah perdarahan banyak (>800 $\mathrm{ml}$ ), sehingga berisiko terjadi proses fibrinolisis yang lebih banyak. Oleh karena itu, pada penelitian sebelumnya pemberian antifibrinolitik sangat signifikan mengurangi jumlah perdarahan. Sebaliknya, pada penelitian ini subyek yang diikutsertakan adalah individu dengan persalinan vaginal yang tidak berisiko terjadi perdarahan banyak (partus fisiologis), sehingga proses fibrinolisis yang terjadi juga minimal, perdarahan yang terjadi sudah dapat diatasi dengan kontraksi uterus dan pemberian uterotonika.

Penurunan kadar hemoglobin pada penelitian ini tidak menunjukkan perbedaan secara bermakna $(0,99 \pm 1,13 \mathrm{ml} v \mathrm{~s} .1,05 \pm 0,93 \mathrm{ml}, p=0,66)$. Penurunan kadar hematokrit juga tidak didapatkan perbedaan secara bermakna $(4,06 \pm 3,73$ vs.4,58 $\pm 4,18, p=0,36)$. Penelitian Gungorduk dkk (2011), mendapatkan hasil rerata kadar hemoglobin dan hematokrit pasca operasi pada kelompok asam traneksamat $(9,9 \pm 0,6$ $\mathrm{g} / \mathrm{dl}$ dan $30,6 \pm 1,5)$ lebih tinggi daripada kelompok plasebo $(9,7 \pm 0,5 \mathrm{~g} / \mathrm{dl}$ dan $30,2 \pm 1,1), p=0,001$ dan $p<0,001{ }^{6}$ 
Asam traneksamat sangat berguna dalam mencegah kasus-kasus perdarahan pascasalin karena faktor selain atonia uteri, di mana uterotonika tidak efektif.Asam traneksamat dapat mengurangi kehilangan darah yang berhubungan dengan komplikasiseperti plasenta previa, trauma saluran genital bawah, dan perdarahan dari segmen plasenta bagian atas. Penggunaan asam traneksamat berpotensi mencegah perdarahan pascasalin terutama pada wanita yang mempunyai faktor risiko. ${ }^{7}$

Kejadian efek samping setelah pemberian asam traneksamat pada penelitian ini berupa mual (1\%), muntah (1\%). Penelitian lain menunjukkan bahwa terjadi keluhan gastrointestinal sebanyak $2,1 \%,{ }^{8}$ bahkan ada yang lebih tinggi sampai sebesar $7,9 \%{ }^{6}$

\section{KESIMPULAN DAN SARAN}

Jumlah perdarahan kala IV, penurunan kadar hemoglobin dan kadar hematokrit sebelum dan setelah 24 jam pascasalin pada persalinan vaginal setelah pemberian asam traneksamat tidak berbeda dibandingkan dengan plasebo.Kejadian efek samping mual dan muntah pada pemberian asam traneksamat tidak berbeda dibandingkan dengan plasebo.

\section{DAFTAR PUSTAKA}

1. Shanghvi H, Lewison D. 2006. Preventing mortality from postpartum hemorrhage in Africa: Moving from research to practice. JHPIEGO. Baltimore, Maryland. April.
2. Badan Pusat Statistik (BPS), Badan Koordinasi Keluarga Berencana Nasional (BKKBN), Kementrian Kesehatan, ICF Internasional. 2013. Indonesia Demographic and Health Survey 2012. Jakarta, Indonesia: BPS, BKKBN, Kemenkes, and ICF International.

3. Ramanathan G, Arulkumaran S. 2006. Postpartum Hemorrhage. J Obstet Gynaecol Can. November, 28(11): 967-973.

4. Bouthors A, Jude B, Duhamel A, Broisin F, Huissoud C, Meyer HK. 2011. High-dose tranexamic acid reduces blood loss in postpartum haemorrhage. Critical Care. 15: 117.

5. Mayur G, Purvi P, Ashoo G, Pankaj D.2007. Efficacy of tranexamic acid in decreasing blood loss during and after cesarean section: A randomized case controlled prospective study. J Obstet Gynecol India. May/June. Vol. 57, No. 3: 227-230.

6. Gungorduk K, Yildirim G, Asicioglu O, Gungorduk OC, Sudolmus S, Ark C. 2011. Efficacy of intravenous tranexamic acid in reducing blood loss after elective cesarean section: a prospective, randomized, double blind, placebo controlled study. American journal perinatology. Oktober. 28: 233240.

7. Gai M, Wu L, Su Q, Tatsumoto K. 2004. Clinical observation of blood loss reduced by tranexamic acid during and after caesarian section: a multicenter, randomized trial. European Journal of Obstetrics \& Gynecology and Reproductive Biology. 112: 154-157.

8. Novikova N, Hofmeyr GJ. 2010. Tranexamic acid for preventing postpartum haemorrhage (Review). The Cochrane Collaboration.Issue 7. 